\title{
Minimasi Waktu Produksi Sepatu Allstar Type Chuck Taylor Low Cut Menggunakan Value Stream Mapping (VSM) dan Penjadwalan
}

\author{
Widy Setyawan ${ }^{1}$, Iwan Maifal ${ }^{2}$, \\ ${ }^{1,2}$ Teknik Industri Universitas Suryakancana \\ Jl Pasir Gede Raya, Cianjur \\ 1idy setyawan@yahoo.com \\ ${ }^{2}$ maifalsajoo@gmail.com
}

Dikirimkan: 10, 2017. Diterima: 12, 2017. Dipublikasikan: 12, 2017.

\begin{abstract}
CV.Cipendawa is a shoe company, which was established in 2005. The brand of goods produced is Allstar shoes, which become main products. Problems that occur in the process of shoe production Allstar is a waste in the form of idle time (idle time). Waste in the form (idle time) occurs because the company does not pay attention to the existence of alternative Allstar shoe assembly making the engine scheduling less good. This research is done by using lean manufacturing and machine scheduling, in lean manufacturing concept in using the operation of process chart (OPC) and value stream mapping (VSM) to describe the value in production process which includes material and information flow. While the machine scheduling is used to reschedule the production process of Allstar shoes so it is expected to reduce waste. The purpose of this research is to minimize product completion time by paying attention to assembling alternatives in the production floor. The results of this study indicate that with Machine Scheduling that pay attention to the order of assembly in get the production completion time of 718 seconds and the waiting time of 114 seconds. And on making a single shoe score add value of 7102 seconds
\end{abstract}

Keyword : value stream mapping; machine scheduling; operation process chart

Abstrak- CV. Cipendawa adalah sebuah perusahaan sepatu, yang berdiri pada tahun 2005. Jenis produk yang di hasilkan sepatu Allstar, yang menjadi produk unggulan. Permasalahan yang terjadi pada proses produksi sepatu Allstar adalah adanya pemborosan waktu menganggur (idle time). Pemborosan ini terjadi karena perusahaan tidak memperhatikan adanya alternatif perakitan sepatu, sehingga membuat penjadwalan mesin kurang baik. Penelitian ini di lakukan dengan menggunakan Lean Manufacturing dan Penjadwalan Mesin, dalam konsep Lean Manufacturing di gunakan Operasi Proses Chart (OPC) dan Value Stream Mapping (VSM) untuk menggambarkan nilai dalam proses produksi yang meliputi aliran material dan informasi. Sedangkan Penjadwalan Mesin digunakan untuk menjadwal ulang proses produksi sepatu Allstar sehingga diharapkan dapat mengurangi pemborosan. Tujuan dari penelitian ini adalah untuk minimasi waktu penyelesaian produk dengan memperhatikan alternatif perakitan di lantai produksi. Hasil penelitian ini menunjukan bahwa dengan Penjadwalan Mesin yang memperhatikan urutan perakitan di dapatkan waktu penyelesaian produksi sebesar 718 detik dan waktu tunggu sebesar 114 detik. Pada pembuatan sepatu dengan jumlah satu kodi memberikan nilai tambah sebesar 7102 detik

Kata kunci: value stream mapping; penjadwalan mesin; diagram proses operasi 


\section{PENDAHULUAN}

\subsection{Latar Belakang}

CV. Cipendawa merupakan salah satu Industri Usaha Kecil Menengah (UKM) yang sedang merintis usahanya. Saat ini Pemerintah telah memberikan perhatian khusus kepada para pelaku UKM dalam memberdayakan usahanya secara optimal, menyeluruh dan berkesinambungan melalui pengembangan yang konklusif sesuai dengan amanat Undang-Undang Republik Indonesia nomor 20 tahun 2008 tentang Usaha Mikro, Kecil dan Menengah. CV. Cipendawa dalam kegiatan usahanya memproduksi beberapa macam jenis sepatu. Perusahaan ini berlokasi di Jl. Raya Pacet, Kabupaten Cianjur. Dalam usahanya Perusahaan ini menerima pesanan atau order dari beberapa konsumen dan pelanggan tetapnya. CV. Cipendawa menganut sistem produksi make to order atau membuat produk berdasarkan pesanan, sehingga selalu dituntut untuk tepat waktu dalam menyelesaikan produknya. Berdasarkan wawancara dengan Manajer Produksi, perusahaan belum mampu menyelesaikan produksi sesuai due date yang diberikan oleh buyer dikarenakan pada proses produksinya terdapat permasalahan yang sering terjadi yaitu pemborosan dalam bentuk waktu menganggur (idle time) dan waktu tunggu. Sehingga completion time proses produksi sepatu All Star Tipe Chuck Taylor Low Cut menjadi lebih lama. Untuk mendapatkan completion time yang lebih pendek maka perusahaan perlu mengurangi pemborosan waktu yang ada, dengan demikian produktivitas perusahaan meningkat.

Pemborosan yang terjadi di CV. Cipendawa disebabkan oleh idle time dan waktu tunggu. Hal ini dikarenakan perusahaan tidak memperhatikan proses alternatif dalam perakitannya. Salah satu pendekatan yang dapat digunakan untuk mengurangi pemborosan adalah Lean Manufacturing, yang dapat didefinisikan sebagai sebuah pendekatan sistematis untuk mengidentifikasi dan meminimasi pemborosan secara terus-menerus dan berkelanjutan, sehingga mampu menarik perhatian konsumen dengan aliran produksi yang lancar [1] (Hines dan Taylor, 2000). Metode penjadwalan pada penelitian digunakan untuk menjadwalkan ulang proses produksi sepatu All Star Tipe Chuck Taylor Low Cut, sehingga diharapkan dapat mengurangi pemborosan dalam bentuk idle time dan waktu tunggu. Penjadwalan adalah pengalokasian sumber daya atau mesin-mesin yang tersedia untuk menjalankan sekumpulan tugas dalam jangka waktu tertentu [2] (Baker, 1974). Penelitian [3] Babayan dan He (1995), menguraikan tentang penjadwalan mesin yang memperhatikan urutan perakitan. Dalam penelitian tersebut ukuran kinerja yang digunakan adalah meminimasi makespan. Hasil dari penelitian tersebut akan dipergunakan sebagai dasar untuk melakukan pengurangan pemborosan pada $\mathrm{CV}$ Cipendawa.

Value stream mapping (VSM) adalah salah satu alat yang digunakan untuk memetakan aliran produksi, intinya adalah untuk mengungkapkan waktu proses value added dan mengukapkan pemborosan waktu untuk proses non-value added [4]. Berdsarkan uraian latar belakang tersebut, penelitian ini akan menngunakan metode VSM dan penjadwalan sehingga nantinya mendapatkan perbaikan terhadap proses pembuatan sepatu All Star Tipe Chuck Taylor Low Cut.

\subsection{Perumusan Masalah}

Adapun rumusan masalah dari penelitian ini adalah bagaimana meminimasi waktu tunggu pada proses pembuatan sepatu All Star Tipe Chuck Taylor Low Cut dengan menggunakan pendekatan Lean Manufacturing?

\subsection{Tujuan Penelitian}

Tujuan yang ingin di capai penelitian ini adalah menghasilkan vsm setelah perbaikan.serta menghasilkan jadwal produksi dengan memperhatikan alternatif perakitan sehingga dapat meminimasi waktu penyelesaian

\section{Metodologi Penelitian}

Studi Literatur dilakukan untuk mendukung penyelesaian proses 
pengumpulan dan pengolahan data dalam penelitian ini.

Studi lapangan dilakukan di CV. Cipendawa, bertujuan untuk mengetahui kondisi awal perusahaan, serta memahami proses produksi Sepatu All Star Tipe Chuck Taylor Low Cut. Pada Tahap pelaksanaan studi lapangan didapatkan data-data sebagai berikut :

1. Data jumlah operator dan jumlah mesin di setiap stasiun kerja.

2. Data waktu proses dan urutan proses kerja.

3. Urutan Perakitan.

Pengolahan data penelitian dilakukan dalam beberapa tahap yaitu:

1. Pembutan Operation Process Chart (OPC)

2. Pembuatan Value Stream Mapping (VSM) Awal

3. Penentuan Aktivitas yang memberikan nilai tambah dan aktivitas yang tidak memberikan nilai tambah

4. Penyusunan urutan perakitan

5. Penyusunan penjadwalan produksi

6. Penggambaran Value Stream Mapping (VSM) Perbaikan

\section{HASIL PENELITIAN}

Berdasarkan pengumpulan dan pengolahan data, didapatkan hasil sebagai berikut.

\subsection{Data Input}

Data input awal yang didapatkan yaitu data jumlah operator dan jumlah mesin ditiap stasiun kerja, data waktu proses dan urutan proses kerja, serta data urutan Perakitan. Data-data tersebut disajikan pada Tabel I, II, dan Gambar 1.

Urutan perakitan penting untuk diperhatikan sebelum melakukan proses penjadwalan. Dari sebuah urutan perakitan dapat diketahui komponen apa saja yang dibutuhkan pada awal proses perakitan. Berdasarkan Gambar 1, komponen upper, texon, toe cap, outsoul, foxing, Bumper adalah komponen yang memiliki urutan perakitan yang paling awal pada awal proses perakitan, sehingga pada proses penjadwalan komponen tersebut dijadwalkan terlebih dahulu.
Berikut tabel data jumlah operator dan jumlah mesin serta data proses dan urutan kerja

Tabel I

DATA JUMLAH OPERATOR DAN JUMLAH

MESIN

\begin{tabular}{|c|c|c|c|c|}
\hline \multicolumn{5}{|c|}{ Stasiun Kerja dan Jumlah Operator } \\
\hline Stasiun Kerja & No & Unutan Prosesproduksi & Jumlah Operator & Jumlah Mesin \\
\hline Stasiun Kerja & 1 & pemolaaan dan pemotongan upper dan Insol & 2 & 1 \\
\hline Stasiun Kerja & 2 & Penjaitan Upperdan Insol & 6 & 6 \\
\hline Stasiun Kerja & 3 & Pelubangan dan pemasangan Kancing (eye late) & 1 & 1 \\
\hline Stasiun Kerja & 4 & pengagabungan Texon board dan upper & 2 & 1 \\
\hline Stasiun Kerja & 5 & Toe cap laste & 2 & . \\
\hline Stasiun Kerja & 6 & Outsoul & 2 & - \\
\hline Stasiun Kerija & 7 & pemolaan(Foxing) & 1 & . \\
\hline Stasiun Keria & 8 & penggabungan (Foxing) & 2 & . \\
\hline Stasiun Kerija & 9 & Bumperdan logo & 2 & 1 \\
\hline Stasiun Kerija & 10 & Diperiksa & 1 & . \\
\hline Stasiun Kerija & 11 & Dloven & 2 & 1 \\
\hline Stasiun Kerija & 12 & Diperiksa & 1 & . \\
\hline Stasiun Kerja & 13 & Pendinginan & 2 & . \\
\hline Stasiun Kerija & 14 & Diperiksa & 1 & . \\
\hline Stasiun Kerija & 15 & Pembersihan dan packaging & 4 & . \\
\hline & & Total & 31 & 11 \\
\hline
\end{tabular}

Tabel II

WAKTU PRSOSES DAN URUTAN WAKTU KERJA

\begin{tabular}{|c|c|c|}
\hline \multicolumn{3}{|c|}{ Waktu Proses Dan Urutan produksi } \\
\hline komponen & Urutan Proses & WP/(Detik) \\
\hline pemolaaan dan pemotongan upper dan Insol & \multirow{2}{*}{ Mesin cutting } & 313 \\
\cline { 1 - 1 } pemolaaan dan pemotongan upper dan Insol & & 199 \\
\hline Penjaitan Upper dan Insol & Mesin sewing & 74 \\
\hline Pelubangan dan pemasangan kancing(eye late) & Mesin poncing & 153 \\
\hline penggabungan Texon board dan upper & Mesin obras & 93 \\
\hline Toe cap & Di pola & 87 \\
\hline Outsoul & Di lem & 73 \\
\hline pemolaan(Foxing) & Di lem & 94 \\
\hline penggabungan (Foxing) & Di lem & 115 \\
\hline Bumper dan logo & Di lem dan di press & 66 \\
\hline Di periksa & Di periksa & 55 \\
\hline Dl oven & Di oven & 4800 \\
\hline Di periksa & Di periksa & 55 \\
\hline Pendinginan & Pendinginan & 1800 \\
\hline Di periksa & Di periksa & 55 \\
\hline Pembersihandan packaging & Pembersihan dan packaging & 1035 \\
\hline \multicolumn{2}{|c}{} & \\
\hline \multicolumn{2}{|c|}{}
\end{tabular}

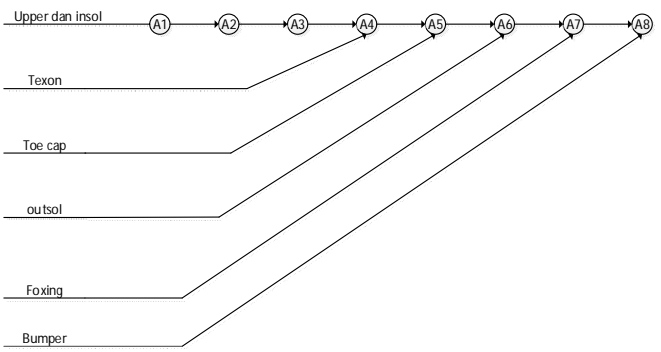

Gambar 1. Urutan perakitan sepatu ALL STAR Tipe Chuck Taylor Low Cut

\subsection{Hasil Pengolahan Data}

Hasil pengolahan data terdiri dari OPC awal, penentuan proses value added dan 
non-value added, VSM awal, penjadwalan produksi awal, perbaikan penjadwalan produksi, dan perbaikan VSM.

\subsubsection{Operation Process Chart (OPC) Awal}

Berdasarkan data input awal, disusun OPC awal untuk produk dengan total waktu 9967 detik, dan terdapat delay se 2700 besar detik.

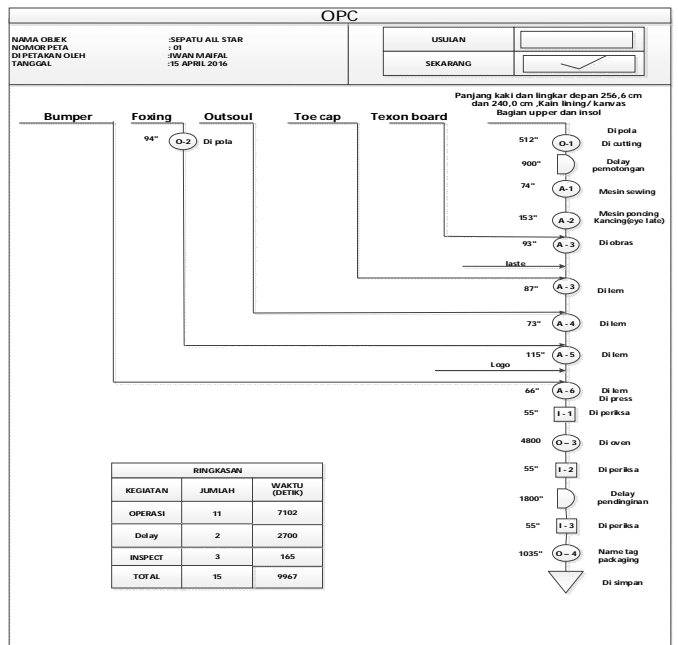

Gambar 2. Operation Process Chart awal untuk produk sepatu ALLSTAR tipe Tipe Chuck Taylor Low Cut

\subsubsection{Penentuan proses value added \& non- value added}

Aktivitas yang memberikan nilai tambah dan yang tidak ditentukan berdasarkan pengamatan yang dilakukan pada lantai produksi. Aktivitas yang memberikan nilai tambah dan aktivitas yang tidak memberikan nilai tambah dijelaskan pada Tabel III berikut.

Berdasarkan Tabel III, dapat diketahui bahwa pada proses pembuatan sepatu terdapat 7102 detik aktivitas yang memberikan nilai tambah, dan aktivitas yang tidak memberikan nilai tambah sebesar 24.465 detik.

\subsubsection{Value Stream Mapping (VSM) Awal}

Penggambaran Value Stream sistem produksi ALL STAR Tipe Chuck Taylor Low Cut di CV. Cipendawa dimulai dari proses pemesanan bahan baku ke supplier, proses perencanaan produksi, proses produksi, sampai dengan produk siap dikirim ke konsumen. Skema yang menggambarkan Value Stream Mapping (VSM) proses pembuatan ditunjukkan gambar pada Lampiran 1.

Tabel III

PRSOSES DAN WAKTU VALUE ADDED \& NONVALUE ADDED

\begin{tabular}{|c|c|c|c|c|}
\hline Aktivitas & Komponen & Proses Produksi & Value Added Time & Non Value Added Time \\
\hline & & $\begin{array}{l}\text { Inpeksi Bahan baku } \\
\text { Delay }\end{array}$ & & 21.600 \\
\hline 1 & $\begin{array}{c}\text { Kain lining / } \\
\text { kanvas } \\
\text { upper dan } \\
\text { insol } \\
\end{array}$ & $\begin{array}{c}\text { perpindahan bahan } \\
\text { baku ke area } \\
\text { pemolaan dan pengukuran } \\
\text { pemotongan/cutting }\end{array}$ & 512 & \\
\hline & & Delay & & 900 \\
\hline 2 & ass (upper) & Ke area ass 1 (stiching/mesin sewing & 74 & \\
\hline 3 & ass (kancing) & Dari sewing ke area ass 2 (mesin poncing) & 153 & \\
\hline 4 & $\begin{array}{c}\text { ass texon dan } \\
\text { upper }\end{array}$ & $\begin{array}{c}\text { Dari poncing ke area ass } 3 \text { texon dan } \\
\text { upper (mesin obras) }\end{array}$ & 93 & \\
\hline 5 & ass toe cap & Dari ass 3 ke area ass 4 toe cap (Di lem) & 87 & \\
\hline 6 & ass outsol & $\begin{array}{c}\text { Dari area ass } 4 \text { ke ass } 5 \text { outsol dan } \\
\text { upper(Dil lem) }\end{array}$ & 73 & \\
\hline 7 & pemolaan foxing & & 94 & \\
\hline 8 & ass foxing & Ass 5 ke area ass 6 foxing (Di lem) & 115 & \\
\hline 9 & \begin{tabular}{|c|}
$\begin{array}{c}\text { ass bumper dan } \\
\text { logo }\end{array}$ \\
\end{tabular} & $\begin{array}{l}\text { Ass } 6 \text { ke area ass } 7 \text { bumper dan logo } 0 \\
\text { (Di lem) }\end{array}$ & 66 & \\
\hline 10 & & Inpeksi(Quality) & & 55 \\
\hline 11 & & Dioven & 4800 & \\
\hline 12 & & Inpeksi(Quality) & & 55 \\
\hline 13 & & Pendinginan & & 1800 \\
\hline 14 & & Inpeksi(Quality) & & 55 \\
\hline 15 & & Name tag pembersihan packaging & 1035 & \\
\hline \multicolumn{3}{|r|}{ Total } & 7102 & 24.465 \\
\hline
\end{tabular}

Penjelasan gambar VSM pada proses pembuatan, adalah sebagai berikut :

1. Konsumen memesan Sepatu All Star Tipe Chuck Taylor Low Cut kepada CV. Cipendawa melalui bagian pemasaran. Kemudian bagian pemasaran memberikan informasi kepada manajer produksi. Selanjutnya manajer produksi memberikan informasi kepada bagian pengadaan dan supervisor lantai produksi.

2. Bagian pengadaan melakukan pemesanan bahan baku ke supplier berupa bahan baku Compound dari CV. Dian Anugrah, bahan baku karet dari CV. Dwi Tunggal dan bahan baku upper dari CV. Lima Saudara.

3. Supervisor lantai produksi memeriksa kualitas dan jumlah bahan baku tersebut.

4. Supervisor lantai produksi berkoordinasi dengan semua operator stasiun kerja untuk melakukan proses produksi sesuai dengan pesanan.

Berdasarkan VSM awal, dapat di ketahui lead time proses pembuatan Sepatu All Star 


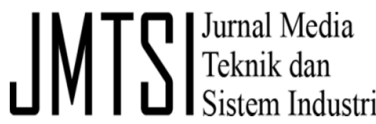

sebesar 24.465 detik dan proses Value Added sebesar 7.102 detik.

\subsubsection{Penjadwalan Awal}

Deskripsi penjadwalan produksi awal dilakukan dengan menggunakan Digraph dan Gantt Chart, seperti pada Gambar 3 dan 4.

Hasil pembuatan Gantt chart pada proses pembuatan didapat waktu Completion Time sebesar 832 detik, waktu perakitan sebesar 435 detik, dan waktu menganggur (Idle Time) sebesar 114 detik. Idle time di dapatkan dari hasil pengurang waktu pemotongan upper dan insol. Cara penjumlahan hanya menambahkan waktu semua proses nya, waktu menganggur atau idle time berapa waktu yang terbuang pada proses pemotongan dan waktu perkitan hanya menanmbah kan waktu proses assembly pada proses pembuatan sepatu All Star Tipe Chuck Taylor Low Cut. Dan setelah itu hasil penjumlahan dari menit menjadi satuan detik

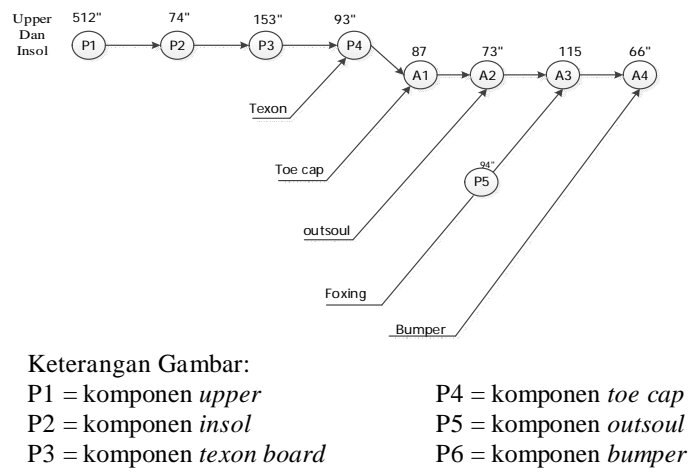

Gambar 3. Digraph awal proses perakitan All Star Tipe Chuck Taylor Low cut.

Pada digraf ini hanya menghitung waktu perakitan.

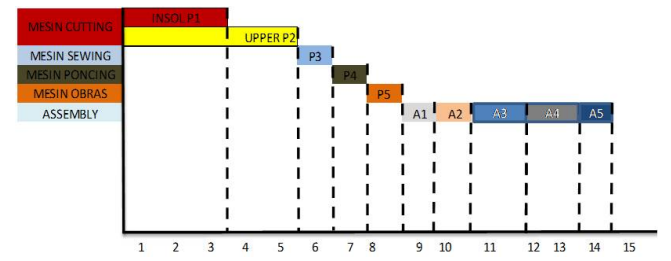

Gambar 4. Gantt chart penjadwalan awal produksi All Star Tipe Chuck Taylor Low Cut.

\subsubsection{Perbaikan Penjadwalan}

Pada penelitian ini, Heuristic Algorithm digunakan untuk menyusun perbaikan proses penjadwalan produksi. Pada perbaikan penjadwalan mesin cutting menjadi 2 unit (sehingga pemotongan insol dan outsol dapat bersamaan) ,dan menyatukan proses assembly texon board pada P3 (menjadi satu proses assembly) sehingga waktu penyelesaian menjadi lebih pendek.

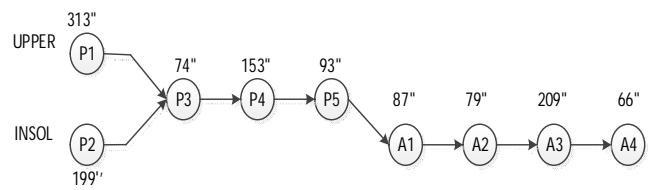

Gambar 5. Digraph perbaikan proses perakitan All Star Tipe Chuck Taylor Low cut.

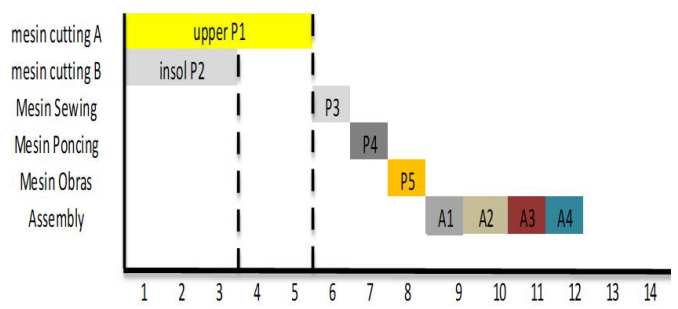

Gambar 6. Gantt chart penjadwalan perbaikan produksi All Star Tipe Chuck Taylor Low Cut.

Berdasarkan perbaikan penjadwalan, didapatkan waktu completion time sebesar 750 detik, dan waktu idle sebesar 114 detik.

\subsubsection{Perbaikan Value Stream Mapping (VSM)}

Penyusunan VSM pada bagian ini untuk menggambarkan Value Stream Sistem produksi setelah dilakukan perbaikan (future state mapping). Penggambaran perbaikan VSM proses pembuatan sepatu ditunjukkan gambar pada lampiran 2.

Dari perbaikan VSM yang ditunjukan pada Lampiran 2 dapat diketahui bahwa lead time proses pembuatan satu pasang sepatu berkurang sebesar 114 detik dengan pengurangan waktu delay pada messin cutting, sehingga lead time proses pembuatan menjadi 24,135 detik. 


\section{PEMBAHASAN}

\subsection{Analisis Value Stream Mapping (VSM) Awal Proses Pembuatan Sepatu All Star Tipe Chuck Taylor Low Cut.}

Kondisi awal pembuatan sepatu dimulai dari pemesanan bahan baku ke supplier, dilanjutkan dengan proses produksi yang meliputi peroses penyortiran bahan baku, pemolaan dan pemotongan, penjahitan komponen upper atau sewing, pelubangan kancing atau pasang mata ayam, pengobrasan upper dan texon, pengeleman toe cap, pengeleman dasar upper dan outsoul, penggabungan upper dan outsoul, pembentukan pola foxing, pengeleman logo dan bumper, pemanasan atau pengovenan, packing, dan pengiriman ke konsumen. Berdasarkan penggambaran VSM bahwa setelah bahan baku datang langsung dilakukan penyortiran selama 1 hari, maka dalam proses penjadwalan perbaikan waktu proses penyortiran bahan baku, pengovenan, packing diperhitungkan, sehingga lead time proses satu unit produksi sepatu All Star sebesar 24.465 detik.

Berdasarkan VSM awal, pada proses produksi didapatkan aktivitas yang memberikan nilai tambah dan yang tidak, meliputi penyortiran bahan baku, pengovenan, dan banyaknya waktu pengerjaan yang menunggu pada proses pemolaan dan pemotongan cutting. Sedangkan aktivitas yang tidak memberikan nilai tambah adalah saat pemotongan bahan baku yang terlalu lama, dikarenakan jumlah produksi melebihi kapasitas mesin sehingga terjadi penumpukan dan waktu yang terbuang.

Untuk mengurangi pemborosan tersebut digunakan penjadwalan produksi, sehingga diharapkan waktu proses produksi menjadi lebih cepat dan lead time proses produksi menjadi lebih pendek.

4.2 Analisis Penjadwalan Proses Produksi Sepatu All Star Type Chuck Taylor Low Cut

Proses penjadwalan produksi sepatu All Star perbaikan dilakukan dengan menggunakan metode heuristic algorithm. Tahap awal produksi pada proses pembuatan ini adalah dengan membuat digraph, kemudian menjadwalkan proses produksi.

Sebelum penjadwalan produksi perbaikan, dilakukan penjadwalan proses produksi awal untuk mengetahui proses penjadwalan yang dilakukan perusahaan. Setelah dilakukan penjadwalan awal didapat waktu penyelesaian produksi sebesar 832 detik dan waktu menunggu (idle time) sebesar 114 detik. Berdasarkan penjadwalan produksi perbaikan didapat waktu penyelesaian sebesar 718 detik dan waktu tunggu sebesar 114 detik pada pembuatan sepasang sepatu.

4.3 Analisis Value Stream Mapping Perbaikan Proses Pembuatan Sepatu All Star Tipe Chuck Taylor Low Cut

VSM perbaikan ini digunakan untuk menggambarkan aliran nilai sistem produksi setelah dilakukan perbaikan. Proses pembuatan VSM perbaikan didasarkan pada proses penjadwalan produksi perbaikan.

Proses pemetaan Value Stream Mapping awal dari proses pemesanan bahan baku ke suplier, dilanjutkan dengan proses produksi yang meliputi suplier, dilanjutkan dengan proses produksi yang meliputi proses penyortiran bahan baku, proses pemolaan dan pemotongan sesuai ukuran, penjahitan komponen upper atau sewing, pelubangan kancing atau pasang mata ayam, pengobrasan upper dan texon, pengeleman toe cap, pengeleman dasar upper dan outsoul, penggabungan upper dan outsoul, pembentukan pola foxing, pengeleman logo dan bumper, pemanasan atau pengovenan, packing, dan sampai menjadi produk dikirim ke konsumen. Berdasarkan VSM perbaikan, untuk setiap proses pembuatan satu kodi sepatu, perusahaan mampu mengurangi lead time sebesar 24.465 detik atau 114 detik untuk setiap sepasang sepatu.

\section{KESIMPULAN}

Kesimpulan yang dapat di ambil dari penelitin ini adalah sebagai berikut:

1. Perusahaan dapat mengetahui cara mengurangi pemborosan dengan melihat Value Stream Mapping awal dan Value Stream Mapping setelah perbaikan, selain itu perusahaan juga dapat 


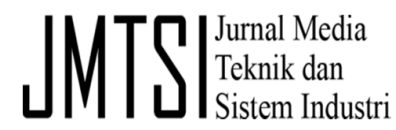

mengetahui aktivitas yang memberikan nilai tambah dan tidak memberkan nilai tambah pada proses pembuatan sepatu. Berdasarkan Value Stream Mapping awal, pada proses pembuatan dalam jumlah satu kodi sepatu perusahaan dapat mengetahui waktu tunggu sebesar 24,465 detik, dan memberikan nilai tambah sebesar 7102 detik. Sedangkan pada Value Stream Mapping perbaikan, perusahaan bisa mengetahui waktu pengurang atau waktu yang berkurang pada nilai yang tidak memberikaan nilai tambah sebesar 24,351 detik.

2. Berdasarkan penjadwalan produksi dengan memperhatikan alternatif perbaikan mengubah dan menambah mesin produksi, maka untuk menyelesaikan satu pasang sepatu dengan cara mengubah mesin diperoleh waktu penyelesaian sebesar 718 detik. Sedangkan dengan cara menambah mesin mampu mengurangi pemborosan waktu tunggu (idle time) sebesar 114 detik. Sehingga waktu penyelesaian produksi sepatu All Star Tipe Chuck Taylor Low Cut menjadi lebih cepat.

\section{PUSTAKA}

[1] Hines, P \& D. Taylor. "Going Lean" Lean Enterprise Research Centre Cardiff Business School. 2000

[2] Baker, Kenneth R. "Pengenalan Sequencing dan Penjadwalan". New York: John Wiley dan Sons, Inc. 1974

[3] French, Simon. 1982. "Sequencing dan Penjadwalan: Pengantar Matematika dari Job Shop". New York: John Wiley dan Sons, Inc.

[4] He, D. \& A. Babayan. "Scheduling manufacturing systems for delayed product differentiation in agile manufacturing". International Journal of Production Research, 40:11, 2461-2481, DOI: 10.1080/00207540210136522. 2002

[5] Hobbs,Dennis P.2004. "Penerapan Lean Manufacturing:Panduan Lengkap Eksekusi Berbagai Ukuran Manufactur”. Florida:J. Ross Publishing,Inc.

[6] Kalsaas, Bo Terje. “Value Stream Mapping, An Adequate Method for Going Lean?”. Paper presented at NOFOMA 2002, the 14th international conference, Trondheim, June 13-14. 2002

[7] Shingo, Shigeo.1990. "A Study Of The Toyota Production System Usa: Andrew”. Dillon Productiviti Press.

[8] Sahoo, A.K., Singh,N. K., Shankar R. dan Tiwari, M. K.2007. "Filosofi Lean: Implementasi Penempaan Sebuah Perusahaan".Journal Internasional Technologi Manufacture, no. 12

Lampiran 1

Value Stream Mapping (VSM) Awal Produksi Allstar Tipe Chuck Taylor Low Cut

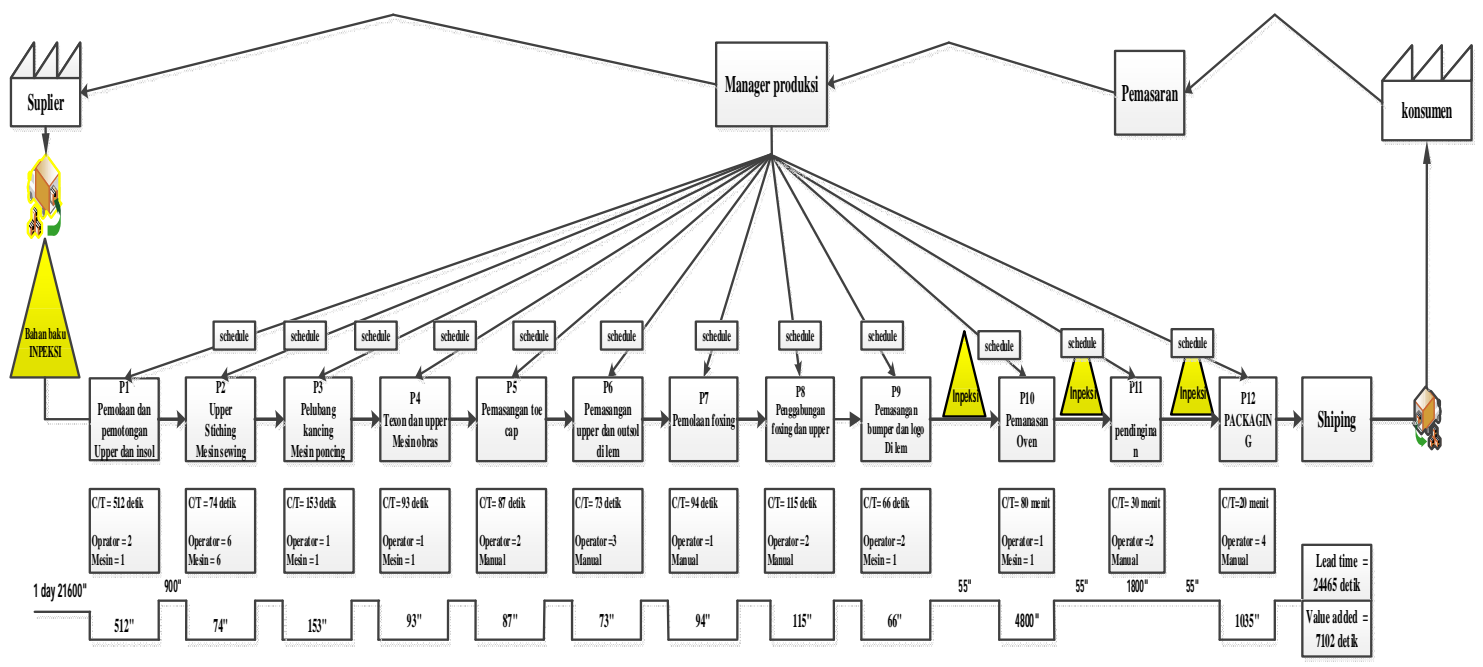


Lampiran 2

Value Stream Mapping (VSM) Perbaikan Produksi Allstar Tipe Chuck Taylor Low Cut

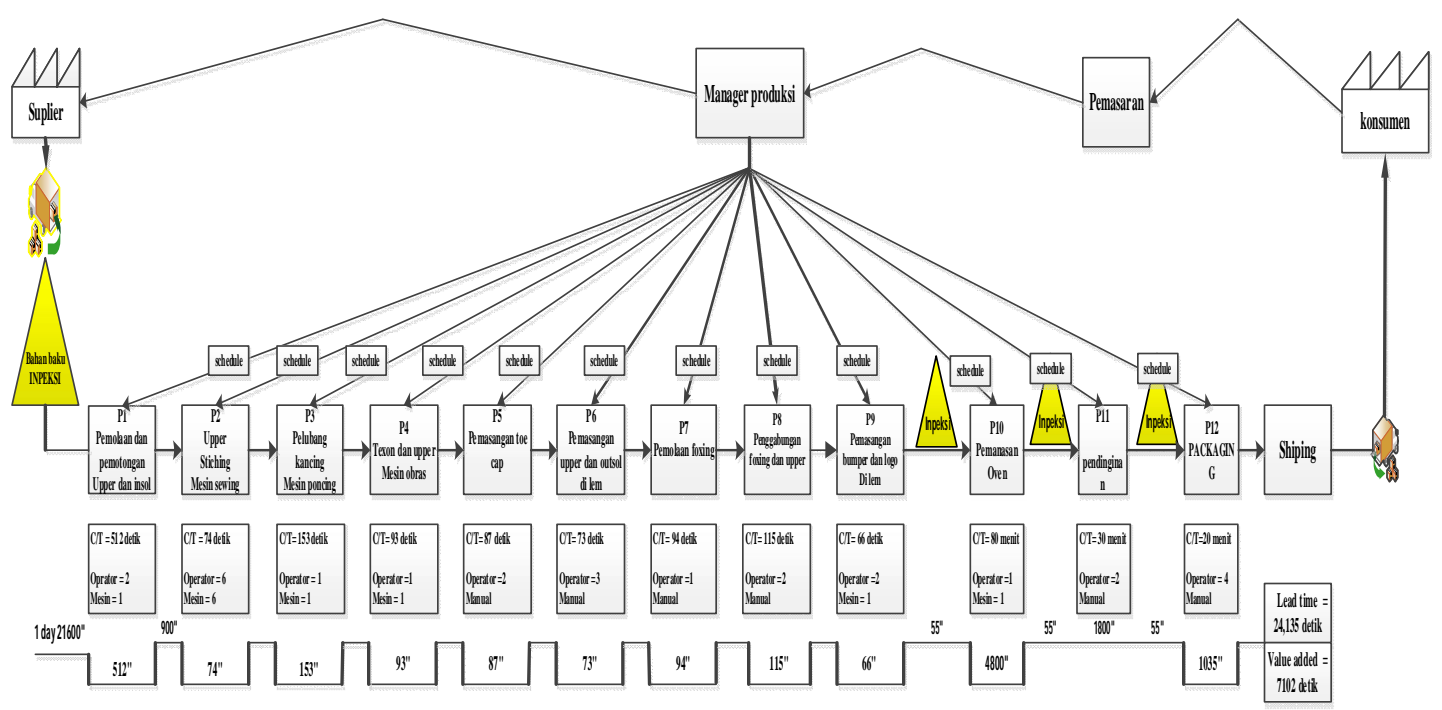

